Seyahat ve Otel İşletmeciliği Dergisi/

Journal of Travel and Hospitality Management

16 (1), 2019, 21-33.

Gönderim Tarihi: 02.10.2018

Kabul Tarihi: 24.12.2018

\title{
Yerli Turistlerin Paket Turlarda Yaptıkları Etik Dışı Davranışlar Üzerine Turist Rehberleri Gözüyle Bir Değerlendirme*
}

\section{An Evaluation in the Eye of Tour Guides on Local Tourists' Unethical Behaviors in Package Tours}

\author{
Dr. Mahmut EFENDi \\ E-posta: efendimahmut926@gmail.com
}

\author{
Dr. Öğr. Üyesi Gülnur KARAKAŞ TANDOĞAN \\ Adnan Menderes Üniversitesi \\ Turizm Fakültesi \\ E-posta: gulnurkarakas@hotmail.com
}

\section{Öz}

Turizm sektörünün gelişimi günümüzde dikkat çekicidir ve bu büyümenin daha doğru olması adına etik değerlerin sektörde yer etmesi önemlidir. Bugüne kadar işletmelerin ve çalışanların etik kapasiteleri değerlendirilmesine rağmen, turistlerin etik açıdan durumları daha az dikkate alınmıştır. Bu çalışmanın amacı, yerli turistlerin grup paket turlar kapsamında gerçekleştirdikleri etik dışı davranışların turist rehberlerinin bakış açısıyla değerlendirilmesidir. Bu amaçla yerli turistler ile tura katılım sağlayan yedi adet turist rehberinden odak grup yöntemi ile veriler toplanmış ve toplanan veriler içerik analizinden geçirilerek araştırmaya dahil edilmiştir. Araştırma kapsamında tamamlanan odak grup çalışmasının sonuçlarına göre dikkat çeken etik dışı turist davranışları yoğunluklu olarak; müze-örenyeri kurallarına uymamak, diğer turistleri rahatsız etmek, programı okumadan tura katılım sağlamak şeklindedir. Tur programına müdahale etmek, rehbere argo tavırlarla hitap etmek, otobüsü kirletmek, emniyet kemeri takmadan yolculuk yapmak, otel ekstralarını ödememek, otobüs kaptanına kötü davranmak, kaptandan geri dönüşlerde duraklar harici yerlerde indirmesini istemek gibi davranışlar da dikkat çekici olarak öne çıkmaktadır.

Anahtar Kelimeler: Etik davranış, Turist rehberi, Paket Turlar, Yerli turistler

\begin{abstract}
The development of the tourism sector is remarkable today and in order for this growth to be more accurate, it is important that ethical values are included in the sector. Despite the fact that ethical capacities of businesses and employees have been assessed until now, ethical aspects of tourists have been considered less. The aim of this study is to evaluate the unethical behaviors that local tourists exhibit during group package tours from tour guides' point of view. For this purpose, the data from seven tour guides providing participation to the tour with local tourists was collected by focus group method and the data collected was included in the research by analyzing through content analysis. According to the results of the focus group study completed within the scope of the research, the most remarkable unethical tourist behaviors are; disobeying the rules of museum-archeological site, disturbing other tourists, and participating in the tour without reading the tour program. Such behaviors as interfering the tour program, talking to the tour guide with slangs, polluting the bus, traveling without wearing a seat belt, not paying hotel extras, behaving the bus driver badly, and asking to get off the bus at places that are not bus stops are also prominent behaviors.
\end{abstract}

Key Words: Ethical behavior, Tour guide, Package tours, Local tourists

${ }^{*}$ Bu çalışma Adnan Menderes Üniversitesi Sosyal Bilimler Enstitüsünde tamamlanan doktora tezinden üretilmiştir. 


\section{Giriş}

Etik, felsefenin bir alanı olmasının yanında, insan davranışlarıyla ilgili olmasından dolayı aynı zamanda turizm ile ilişkili alanlardan biridir. Turizmin evrensel bir olgu olması sebebiyle toplumsal ya da bireysel normlardan çok evrensel normları kapsayan etik kavramı ile yürütülmesi önemlidir. Turizm sektörü içerisinde yer alan konaklama, seyahat ve yiyecek-içecek işletmeleri çalışanlarının ve turistlerin karşılaştıkları etik dışı davranışlar, bu konudaki çalışmaların temelini oluşturmaktadır. Bugüne kadar turizmde etik ile ilgili çalışmalarda daha çok işletme ve çalışanların etik sorumlulukları öne çıkarken, turistlerin etik durumunu araştıran çalışmalar geri planda kalmıştır.

Çoğu zaman turistler, turizmin sosyal ve çevresel etkileri hakkında sınırlı bilgiye, ancak davranışlarının işleri nasıl daha iyiye götürebileceği konusunda ise daha az öngörüye sahiptir. Bazı tüketiciler eylemleri için kendilerini değil, başkalarını veya içinde bulundukları durumları suçlama eğilimindedir. Buda aslında turistlerin belli başlı sorumlulukları olduğunu ve bunun etik turizm ile açıklanabileceğini göstermektedir (Grimwood vd., 2015: 23). Bu çalışma turlarda turistlerle en fazla vakit geçiren rehberlerin bakış açısıyla turistlerin etik dışı davranışlarını keşfetmeyi amaçlamaktadır. $\mathrm{Bu}$ konunun seçilmesinin nedeni; turistlerin çıktıkları turlarda etik dışı davranışlarda bulunma intimalinden ötürü bu davranışlara ve davranışlara bağlı olarak turun gidişatının kötü yönde etkilenecek olmasıdır. Belirlenen etik dışı davranışlar konusunda turistlerin önceden bilgilendirilmesi, olası aksaklıkların da önüne geçilmesinde yardımcı olacaktır.

\section{Etik ve İlgili Kavramlar}

Etik sözcüğü köken olarak eski Yunanca bir sözcük olan "ethos” sözcüğünden gelir. Bu sözcüğün kökeninde ise "ethica" sözcüğü vardır. Buradaki (ethika) sözcüğü, ethos sözcüğünün çoğulu olan (ethe), en eski anlamıyla söylenirse, "canlı bir varlığın 'mekan'ı, 'hep gittiği, sığındığı yer' anlamına" gelmektedir. İlk anlamıyla "bir canlının barındığı, sığındığı yer, ortam" anlamına gelen (ethe) tekili olarak ethos sözcüğü de, karakter, huy demektir (Kuçuradi, 1986: 7).

Etiğin tanımı konusunda ortak bir ifade geliştirmek, kavramın felsefi temelleri nedeniyle birçok bilim insanı için zor olmuştur. Bugün literatürde etikle ilgili birçok tanım yapıldığı görülmektedir. Etik ile ilgili geliştirilen bu tanımların bir kısmı Çizelge 1.1.'de verilmiştir.

Tablo 1: Etik Tanımları

\begin{tabular}{|l|l|}
\hline Dedeoğlu (2004:113) & $\begin{array}{l}\text { Etik, "doğru ya da iyinin ne olduğunu belirtme sanatı, bunun yanında genel bir } \\
\text { yol, yaşam alanı, bir dizi hareket kuralı ya da ahlak ilkesi" olarak } \\
\text { değerlendirildiğini anlarız. }\end{array}$ \\
\hline $\begin{array}{l}\text { Okay ve Okay } \\
(2005: 646)\end{array}$ & $\begin{array}{l}\text { Etik, toplumda yaygın olarak anlaşılan ahlak kurallarından daha özel ve felsefi } \\
\text { bir anlam taşımaktadır. Etik, bir kimse için doğru-yanlış, haklı-haksız ayrımını } \\
\text { anlatabilen bir değer sistemidir. }\end{array}$ \\
\hline Cevizci (2008:11) & $\begin{array}{l}\text { Genel olarak; etik kavramı iyi ve doğruyu ayrıca kötü ve yanlışı da sorgular, } \\
\text { bireyin hayattaki amacının ne olması gerektiği üzerinde düşünmesini sağlayan, } \\
\text { ahlaklı ve erdemli bir hayat sürmesi için hangi tipik özelliklerin nası olması } \\
\text { gerektiğini anlatan bir felsefe bilimi olarak tanımlanmaktadır. }\end{array}$ \\
\hline $\begin{array}{l}\text { Sakarya ve Kara (2010: } \\
57)\end{array}$ & $\begin{array}{l}\text { Etik, hayatımızın her anında, birey toplum ve kurumlar açısından hangi } \\
\text { davranışların doğru veya yanlış olduğu sorusuna cevaplamaya çalışan kurallar } \\
\text { bütünüdür ayrıca etik davranışlar şahsi karar ve tercihlerin ürünüdür. }\end{array}$ \\
\hline
\end{tabular}


Tablo 1'in devamı

\begin{tabular}{|c|c|}
\hline Kuçuradi, (2011:5), & $\begin{array}{l}\text { Etik sözcüğü köken olarak eski Yunanca bir sözcük olan (ethos) sözcüğünden } \\
\text { gelir. Bu sözcüğün kökeninde (ethica) sözcüğü vardır. Buradaki (ethika) } \\
\text { sözcüğü, ethos sözcüğünün çoğulu olan (ethe), en eski anlamıyla söylenirse, } \\
\text { "canlı bir varlığın 'mekan'ı, ‘hep gittiği, sığındığı yer' anlamına" gelmektedir. İlk } \\
\text { anlamıyla "bir canlının barındığı, sığındığı yer, ortam" anlamına gelen (ethe) } \\
\text { tekili olarak ethos sözcüğü de, karakter, huy demektir. }\end{array}$ \\
\hline Pieper (2012: 28) & Etik, iyi olana değil, bir şeyin iyi olduğu hükmüne nasıl varıldığını söyler. \\
\hline Gök (2012: 4) & $\begin{array}{l}\text { Etik kavramı, insan ilişkilerinin temelinde yer alan değerleri, belirli davranış, ilke } \\
\text { ve normları içermekte; doğru, adil, dürüst ve yasal olanın yapılması anlamına } \\
\text { gelmektedir. }\end{array}$ \\
\hline Gülbuğ (2012: 32) & $\begin{array}{l}\text { Etik, insanın kendine ve diğer insanlara karşı iyi davranması, daha genel olarak } \\
\text { iyilik için kendini uymaya zorunlu hissettiği manevi ve ruhsal görevler ve bunlara } \\
\text { bağlı kurallardır. }\end{array}$ \\
\hline Kolçak (2012:3) & $\begin{array}{l}\text { Etik, sosyal bir varlık olan insanın bireysel ve toplumsal ilişkilerinin temelini } \\
\text { oluşturan kurallar ve değerleri, doğru veya yanlış, iyi ya da kötü gibi ahlaki } \\
\text { olarak araştıran bir felsefe disiplinidir. }\end{array}$ \\
\hline $\begin{array}{l}\text { Sökmen ve Tarakçıŏlu } \\
(2013: 20)\end{array}$ & $\begin{array}{l}\text { Ahlak felsefesi olarak tanımlanabilen etik, kişilerin bireysel ve toplumsal } \\
\text { yaşamındaki ahlaki davranışlarıyla alakalı sorunları ele alan ve inceleyen felsefe } \\
\text { dalıdır. Diğer bir ifadeyle, "iyi-kötü", "doğru-yalan", "adalet-adaletsizlik" gibi } \\
\text { değerler ile uğraşan felsefenin bir disiplinidir. }\end{array}$ \\
\hline Stroll A. vd. (2014:8) & $\begin{array}{l}\text { Etik kelimesi çok fazla kullanılmasına rağmen, anlamı tam olarak } \\
\text { açıklanamamış, ayırt edici özelliği meydana çıkmamıştır. Anlamı ile şöhreti } \\
\text { arasında ters bir orantı vardır ve etik kelimesi kullanıldığında, onun akabinde } \\
\text { söylenen sözlerin, yapılan davranışların veya değerlendirmelerin etik olarak } \\
\text { düşünülmesi istenilmesinden dolayı ayırt ediciliği engellenmektedir, Felsef } \\
\text { açıdan etik; "insan davranışları nasıl olmalı" sorusuna yanıt aramaktadır. }\end{array}$ \\
\hline Alkan (2016: 46) & $\begin{array}{l}\text { Etik, ahlakın özünü, ilkelerini araştırarak, ahlaklı olmanın ne olduğunu ortaya } \\
\text { koymaya çalışmaktadır. }\end{array}$ \\
\hline
\end{tabular}

Not: Bu çizelge yazarlar tarafından oluşturulmuştur

Etik tanımlarına bakıldığında kavramın birçok yazar tarafından tanımlandığı görülmektedir ve bunların bütününden elde edilebilecek bilgi, etiğin genel olarak ahlak felsefesi olarak düşünülebileceğini, ahlakın özünü, ilkelerini araştırarak, ahlaklı olmanın ne olduğunu, genel bir yol, belirli davranış, ilke ve normları içerdiğini; doğru, adil, dürüst ve yasal olanın yapılmasını ifade ettiği söylenebilir.

Etiğin ana soruları “iyi olanla"(örneğin "iyi nedir?", “iyi yaşam nedir?" "nasıl yaşamalı?", "etik değerler nelerdir?") ve "özgürlükle ilgili” (örneğin "insan özgür müdür?", “özgürlük nedir?", "insan nelerden sorumludur?") sorularıdır (Güven, 2014: 140). Davranışlara yön veren de, bu sorulara verilecek cevaplar olacaktır. Bu nedenle söz konusu bu kavramlarla ilgili bilgi ve deneyim kapasitesi, kişinin etik veya etik dışı davranışlarının da temelini oluşturmaktadır. Bu bağlamda aşağıdaki kavramlar etiğin açıklanması için güzel bir yöntem oluşturmaktadır. Ayrıca aşağıdaki kavramlar ile beraber etik hakkında daha geniş bilgilere ulaşarak araştırmanın ilerlemesi için bir şekil oluşturmaktadır.

lyi "işe yarar, ereğine, özüne uygun, doğru yapılmış" doğasına uygun, istenmeye değer olan, değere yönelmiş, değere ilişkin, değerlerle belirlenmiş, değerli, ahlakın ve ahlak felsefesinin temel kavramı, ahlaksal değer; ahlaksal olanın olumlu ana niteliğini gösteren özel kavram; ahlakça değerli olan manasına gelmektedir (Akarsu, 1984: 108).

Kötü ise "değersiz bulmanın, kınamanın, ayıplamanın konusunu içinde olan her şey veya ahlak değerlerine ve törel istence karşı olan her şey" demektir (Akarsu, 1984: 121). 
Özgürlük, etiğin temel hedefidir (Dedeoğlu, 2004: 144) ve etik özgürlük bir kişi özelliğidir: bir kişi değeri ya da etik bir değerdir. Özgür kişi yaşarken, insan ilişkilerinde en fazla iyiyi yaptığı kadar doğru ve değer bilgisini de bu hesaba katarak eylemlerini tamamlayan kişidir (Kuçuradi, 2014: 7). Bunun yanında hiçbir özgürlük mutlak, her şeyi kapsayıcı, sınırsız değildir (Bauman, 2016: 122).

Erdem, sözlük anlamı olarak istencin ahlaksal iyiye yönelmesi veya insanın tinsel ve ruhsal yetkinliğidir (Akarsu, 1984: 70).Görülmektedir ki erdem övülen huylardır ve erdem düşüne düşüne seçilen bir huydur, bize göre orta olan, akıl tarafından ve uslu kişinin belirleyeceği şekilde belirlenen huydur (Tepe, 1998: 19).

Adalet kavramı yaygın olarak, hem genel kural ve ilkeler hem de bireylerin karşılaştığı belirli durumlarda fayda sağlaması adına oluşturulan özel kurallar için kullanılmaktadır (Arslan vd., 2007: 14). Platon ve Aristoteles'ten beri, herkese kendine uygun düşeni, kendi hakkı olanı verme demek olan bir doğruluktur. Doğru olarak kabul edilmiş olan ile uzlaşma veya herkesin hakkının yasalarla tanınmış olması anlamına gelir (Akarsu, 1984: 17).

Vicdan, insanın iç sesine verilen isimdir ve davranışlarımızın ahlaki açıdan kendi içimizde değerlendirilmesidir ve kendi kendine hesap verebilmedir (Keskin, 2014: 11). Kişinin kendi kendini yargılama yeteneğini kullanması sonucu, niyet ve eylemlerinin ahlaki değerlerinin bilincine varmasını sağlayan ahlaki yeterliliktir. Vicdan, kişinin iyiliğine veya kötülüğüne dair benliğinde oluşan ahlaki bir buyruk niteliğinde yargısal bilinçtir (Sökmen ve Tarakçıoğlu, 2013: 31)

Ödev ve yükümlülükler, davranışın veya gerekli olduğu halde davranmamanın meydana getirdiği potansiyel bedeli, görev ve zorunlulukları kabul etmektir (Dedeoğlu, 2016: 104). Kişinin iyi veya kötü arasından birini tercih etmesinin ortaya çıkardığı sonuçlardır ve yapılan bu davranışların sonucunda doğru veya yanlışın üstlenilmesidir. (Keskin, 2014: 11). Toplumda yaşayan bireylerin ve organizasyonların yaptıkları her türlü davranışla ilgili, başkalarına ve topluma karşı sorumlulukları bulunmaktadır (Kozak ve Nergiz, 2016: 65).

\section{Turizm ve Etik}

Etik, felsefenin bir alanı olmasının yanında, insan davranışlarıyla ilgili olmasından dolayı turizm ile ilişkili alanlardan bir tanesidir. Kant'ın "Koşulsuz Buyruğu" olan "Sadece evrensel yasa haline gelmesini isteyebileceğin en yüksek kurala uygun eylemde bulun" (Kuehn 2011: 285) ilkesi ile ahlak gibi toplumsal bir olgu olmaktan çıkarak evrensel bir zemine oturtulmuş ve bu yönüyle de turizm gibi kültürlerarası etkileşimin yoğun yaşandığı bir sektör için vazgeçilmez olmuştur.

Turizm sektöründe birçok insanın bir arada beraber zaman geçirmesi gerektiği ve bunların farklı kültürlere sahip olmaları düşünülür ise, etik dikkat edilmesi gereken en büyük konudur çünkü uyum gereklidir. Turizm sektöründe haklar uluslararası yasalara ve sözleşmelere bağlanmış olsa dahi birbirinden farklı durumlarla ve etik dışı davranışlarla karşılaşııması olasıdır (Öter, 2007: 101).

Dünya Turizm Örgütü'nün geliştirdiği etik ilkeler ile birlikte tur operatörleri, seyahat acenteleri, belirli etkinlik katılımcıları, ev sahibi topluluklar ve turistler için belirlenmiş etik kurallar oluşturulmaya çalışılmıştır. Çok sayıda kural (kod) ile ilgili en önemli hedef kitle ziyaretçilerdir. Örneğin, Dünya Seyahat ve Turizm Araştırma Konseyi (WTTRC: The World Travel and Tourism Research Council), 1994 yılında 
dünya genelinde yaklaşık 80 ziyaretçi kuralı listelemiştir. Bu kurallar, turist davranışını etkilemek için geliştirilmiştir. Bunlar, Pasifik Asya Seyahat Birliği (PATA) gibi uluslararası organizasyonlar, Amerikan Acenteleri Topluluğu gibi ulusal organizasyonlar, Turizm Meseleleri gibi Sivil Toplum Örgütleri, Thomson Holidays gibi tur operatörleri ve örneğin O'Grady'nin (1981) Turistler için Etik Kuralları gibi bireyler tarafından üretilmiş ve desteklenmiştir. Birleşmiş Milletler Çevre Programı (UNEP) (1995), turizmde genellikle davranış kurallarına ilişkin beş hedef sıralarken, turistlerle ilgili amaç ve hedefleri büyük oranda net değildir (Cole, 2007: 444).

Amaçlar bir dizi bağlantılı alana ayrılmaktadır: turist farkındalığını arttırmak, turistleri eğitmek, turist güvenini arttırmak, paydaşlar, özellikle de turistler ile yerel halk/ev sahipleri arasındaki çatışmayı önlemek ziyaretçilerin davranışlarını iyileştirmek ve olumsuz ziyaretçi etkilerini azaltmak için bir ziyaretçi yönetim aracı olarak görev yapmaktır. Davranış kuralları, paydaşlar arasında diyalog yaratmanın bir başka yolu olabilir. Bu, turistleri hedef alan davranış kurallarının özel bir amacı değil, üretimlerinin bir sonucudur (Cole, 2007: 444).

Güler ve Kadıoğlu (2017) yaptıkları çalışmada gayri ahlaki müşterileri kategorilendirerek restoran ve otel çalışanlarının, bu tür davranışlar sergileyen turistlerle başa çıkma taktikleri üzerine yoğunlaşmışlardır. Aslan ve Kozak (2012) otel çalışanları ile yaptıkları çalışmalarında, müşterileri; nezaketsizler, sözlü sapkınlık yapanlar, fiziksel sapkınlık yapanlar, suçlular, sözlü cinsel tacizde bulunanlar, fiziksel cinsel tacizde bulunanlar olmak üzere altı farklı gruba ayırmışlar, Sidani vd., (2009) yaptıkları çalışmalarında etik duyarlılık üzerinde durmuşlar ve etik duyarlııı̆ın ahlaki karar verme sürecinin yalnızca bir parçası olduğunu, diğer parçalarının ise; ahlak bilinci, ahlaki yargı, ahlaki amaç ve ahlaki eylem olduğunu belirtmişlerdir. Bunun yanında Cole (2007) yaptığı çalışmasında farklı paydaş gruplarına yönelik çok çeşitli davranış kuralları üretildiğinden ve bu paydaşların tur operatörleri, seyahat acenteleri, belirli etkinlik katılımcıları, ev sahibi topluluklar ve turistler olduğundan bahsetmektedir. Harris ve Reynolds (2004) konaklama işletmeleri çalışanları ile yaptığı çalışmada tazminat mektubu yazarları, arzulanmayan müşteriler, suiistimalciler, kibirli müşteriler, sözlü tacizciler, fiziksel tacizciler, hizmet çalışanları, cinsel tacizciler diyerek sekiz farklı grupta gayri ahlaki müşteri davranışlarını ortaya koymuşlar. Lovelock (1999) hizmet işletmeleri çalışanları ile yaptığı çalışmada, gayri ahlaki davranışta bulunan müşteri tiplerini altı farklı tipte ayırmışlardır. Yapılan çalışmalardan da anlaşılacağı gibi genelde araştırmacılar müşteriler ile çalışanların bir arada ortamları seçmişler genel geçer kurallardan bahsetmişlerdir. Bu araştırma için söylenebilecek olan dikkat çekici durum bireysel davranışların dikkate alınarak turist rehberlerinden alınan bilgiler ışığında turistlerin paket turlarda yapmış oldukları etik dışı davranışların özel olarak ayrılmasıdır.

Genellikle tur operatörleri veya toptancıları tarafından, belirli bir bölgeye yönelik olarak, gidiş ve dönüş tarihleri, konaklama, ulaşım, yiyecek-içecek ve gezi, eğlence yerleri ve fiyatı önceden belirlenmiş olan turizm ve seyahat ürününe paket tur denir (Mısırlı, 2002: 164). Ulaştırma, konaklama ve bunlara yardımcı sayılmayan diğer turistik hizmetlerden en az iki tanesinin birlikte, her şeyin dahil olduğu fiyatla satılan ve en az bir geceleme konaklamayı içeren tur çeşididir (Demircan, 2007: 11).

Ayrıca, turistik ürün girdilerinin maliyetlerinin toplam fiyat içindeki payının tüketici tarafından bilinmediği ve tur operatörü tarafından oluşturulan ulaşım, konaklama ve yan hizmetlerin bir bütün olarak sunulduğu turistik ürün şeklinde adlandırabilir (Yarcan ve Peköz, 1998: 23). Kısa bir tanımla paket tur "seyahat ve tatil ile ilgili değişik unsurların bir araya getirilmesiyle oluşturulan bir hizmet ürünüdür" (Hacıoğlu, 1996: 
70). Paket tur, tüketicilerin tatil gereksinimlerini karşılamak amacıyla ulaştırma ve konaklama ana unsurlarına göre, farklı turizm hizmetlerinin dahil edilip bir bütün olarak belli bir fiyat karşılığında satılan birleşik üründür (Demir, 2017: 114).

Demircan (2007)'e göre paket turların yürütülmesinde görev alan çalışanlardan biri de rehberlerdir. Seyahat rehberleri; turistik amaçla yapılan gezilerde turlarında ve kısa mesafeli gezilerde kişilere ve gruplara refakat ederler, ilginç yerleri tanıtırlar ve rehberlik hizmetlerini sağlarlar.

Rehberler, turda yol gösterici, bilgi verici olarak görev üstlenirler. Yabancı turistler için ilgili dilde güzergâh üzerindeki tarihsel ve doğal çekicilikler konusunda tura katılım sağlayanları ayrıntılı bilgiler vererek mesleklerini icra eden kişilerdir (İçöz, 2014: 183). Tur üyeleri ile yoğun ilişkiler, uzun çalışma saatleri, aileden ve arkadaşlardan uzakta geçen uzun sürelerle birlikle, yoğun yüksek sezonlar ve düşük sezonlar tur rehberliğinin bazı özellikleridir. Bu özellikler tur liderleri için ortadan kaldırması güç zorluklar yaratmaktadır (Tsaur ve Lin, 2014: 28).

\section{Yöntem}

$\mathrm{Bu}$ araştırmanın amacı yerli turistlerin paket turlarda yapmış oldukları etik dışı davranışları rehberlerin bakış açısından tespit etmektir. Turistler çıktıkları turlarda etik dışı davranışlarda bulunabilir ve bu davranışlara bağlı olarak turun katıımcılarının memnuniyet düzeyi yanında turda görevli çalışanların performansları da olumsuz yönde etkilenebilir.

$\mathrm{Bu}$ çalışma kapsamında yerli turistlerin rehberlerin gözüyle etik dışı davranışlarda bulunup bulunmadıklarının tespit edilmesi ve eğer varsa bu davranışların neler olduğunun ortaya konması amaçlanmaktadır. Böylelikle yoğun biçimde tekrarlanan etik dışı davranışlar konusunda turistlerin önceden bilgilendirilerek, olası aksaklıkların da önüne geçilmesine ve paket turların niteliklerinin artırılmasına yardımcı olacak bilgiler sunulması hedeflenmektedir. Bu hedef doğrultusunda aşağıdaki araştırma soruları oluşturulmuştur.

\section{Çalışmanın problemleri;}

Yerli turistler paket turlarda etik dışı davranışlarda bulunmakta mıdırlar? nelerdir?

Turist rehberlerinin paket turlarda karşılaştıkları etik dışı turist davranışları

Bu çalışmada nitel araştırma deseni kullanılmıştır. Nitel yöntemin seçilmesinin nedeni nitel araştırmanın, dünyadaki gözlemcinin yerini tespit eden bir aktivite olmasıdır (Budak ve Budak, 2013: 43). Keşifsel araştırmalar, bir grup veya evreni çalışma, kolaylıkla ölçülemeyen değişkenleri belirleme veya susturulmuş sesleri duyma intiyacından dolayı gereklidir. Literatürde önceden belirlenmiş bilgileri kullanmak yerine, bir problemi keşfetmek için en iyi yoldur. Karmaşık bir konuya ayrıntılı bir anlayış getirmek için nitel araştırma yapılır (Creswell, 2016: 42).

Araştırma kapsamında nitel araştırma yöntemlerinden odak grup çalışması kullanılmıştır. Odak grup görüşmelerin en belirgin özelliği görüşme grubunun bir moderatör etrafında toplanması ve araştırmacının üzerinde çalıştığı konu hakkında görüşlerin bildirilmesi bir beyin fırtınası oluşturularak daha derin ve özel bilgilerin elde edilebilmesidir. 
Odak grup çalışmasının güçlü yönleri, kısa zamanda çok fazla kişiden veri toplanabilmesi ve daha geniş örneklemlerle çalışma fırsatı vermesi ile örneklem büyüklüğü yanında odak grup görüşmeleri etkileşimli süreçler olmasıdır. Buna bağlı olarak bu tip görüşmelerde derin ve zengin bilgi kolayca elde edilebilir (Mil, 2007: 18).

Bu çalışmada odak grup yönteminin kullanılma sebebi daha kolay ve daha fazla bilgiye ulaşma çabasıdır. Öncelikle araştırma kapsamında belirlenen amaç ışığında odak grup görüşmesi için soru taslak halinde hazırlanmış ve konunun uzmanı üç akademisyen ile tartışılarak belirlenmiştir. Daha sonrasında araştırmanın yapılacağı yer belirlenmiş ve kullanılacak olan teknolojik yöntemler (ses kayıt cihazı-cep telefonu kamerası ile kayıt) seçilerek hazır hale getirilmiştir. Bu çalışma katılımcıların kolay iştirak edebilmeleri için Adnan Menderes Üniversitesi Turizm Fakültesi ek binasında yapılmıştır. Turist rehberlerine görüşmeden önce etik kavramı, araştırmanın amacı, kendileri ile böyle bir görüşme yapılmasının gerekliliği ve görüşmenin ses kayıt cihazı ile kaydedileceği, ayrıca görüşme sırasında notlar alınacağı belirtilmiştir. Daha sonra ise turist rehberlerinden kendilerini tanıtmaları istenmiştir. Turist rehberleri isimlerini söyledikten sonra kaç yıldır bu mesleği yaptıklarını belirtmişlerdir. Diğer aşamada turist rehberlerine, araştırmacının katıımlı gözlem sonucunda turlardan elde ettiği verilerden yola çıkarak hazırlanan bir soru sorulmuş ve daha sonra odak grup çalışması sırasında yapılan konuşmalarla beraber araştırmanın odak grup görüşmesi tamamlatılmıştır. Daha sonra belirlenen temalar eşliğinde odak grup görüşmesi verileri içeriz analizi yapılarak sekiz farklı gruba ayrılmış ve bulgularda verilmiştir. Turist rehberlerine bir soru sorulduktan sonra sırasıyla cevap vermeleri istenmiş ve daha sonra hepsiyle bir sohbet ortamı havasında beyin fırtınası yaratılmaya çalışılmıştır. Odak grup görüşmesi süresince sorulan sorular, ulaşılan bilgiler bulgular kısmında ayrıntılı olarak verilmiş ve sonuç-tartışmalar kısmında açıklanmıştır. Toplamda bir saat dokuz dakikalık bir odak grup görüşmesi gerçekleştirilmiştir. Son olarak elde edilen veriler düzenlenerek analiz edilmiştir.

\subsection{Evren ve Örneklem}

Bu çalışmanın evrenini Kuşadası'nda aktif olarak turist rehberliği mesleğini yürüten ve Atro (Aydın Turist Rehberleri Odası)üyesi yedi kişi oluşturmaktadır. Çalışmanın örneklemini Atro üyesi aktif (eylemli) 607 turist rehberi oluşturmaktadır. Bu çalışmada hazırlanan sorular nitel araştırma desenlerinden fenomonoloji (olgu bilim) deseninde hazırlanmıştır. Olgu bilim çalışmalarında farkında olunan ancak derinlemesine ve ayrıntılı bir anlayışa sahip olunamayan olgulara odaklanılması esastır.

Keşifsel araştırmalar, bir grup veya evreni çalışma, kolaylıkla ölçülemeyen değişkenleri belirleme veya susturulmuş sesleri duyma intiyacından dolayı gereklidir. Literatürde önceden belirlenmiş bilgileri kullanmak yerine, bir problemi keşfetmek için en iyi yoldur. Kompleks bir konuya ayrıntılı bir anlayış getirmek için nitel araştırma yapılır (Creswell, 2016: 42).

Nitel araştırmacılar tümevarımsal bir şekilde daha soyut bilgi birimleri şeklinde organize ederek, örüntü, kategori ve temaları "aşağıdan yukarıya" doğru oluşturur. Bu tümevarımsal süreç, kapsamlı bir dizi tema oluşturuncaya dek, temalar ve veri tabaları arasında ileri ve geri çalışan araştırmacıları içerir. Ayrıca, bu süreçte ortaya çıkan temalar veya soyutlamalara şekil verebilmesi için, katılımcılarla etkileşimli bir işbirliği de içerebilir (Creswell, 2016: 45).

Nitel araştırma; araştırmacının araştırılacak konu ya da olayı doğal ortamında incelediği, araştıılan bireyin bu durumlar hakkında zihninde yapılandırdığı anlamları 
belirlemek ve bunları yorumlama gayreti içerisinde olduğu bir araştırma türüdür (Denzin ve Lincoln, 2008). Nitel araştırmalarda, görüşme ve gözlem verilerinin toplanması için gereken zaman, enerji, organizasyon ve para, örneklemin sınırlı tutulmasını gerektirir. Ayrıca, gözlem ve görüşmeler yoluyla elde edilen verilerin yoğunluğu ve çokluğu da bu seçimde rol oynar. En az yarım saatten başlayıp birkaç saate yayılabilecek bir görüşmenin yazıya dökülmesi, yazıya dökülen bu görüşme metninden veya veriden, araştırma problemine ilişkin anlamlı temaların çıkarılması, nitel araştırmalarda yaygın olarak karşılaşılan çalışma biçimidir. Bu nedenle, nitel araştırmalarda örneklem büyüklüğü, nicel araştırmalardaki büyüklüğe çoğu zaman ulaşamamaktadır (Yıldııım ve Şimşek, 2006).

Görüşme, nitel araştırmada temel veri toplama araçlarındandır ve sosyal bilimlerde en sık kullanılan araştırma yöntemlerinden biridir (Yıldırım ve Şimşek, 2006). Görüşme, iki ya da daha fazla sayıda insan arasında belli bir amaç etrafında yapılan tartışmalardır. Yaygın olarak görüşmeler yapılandırılmış, yarı yapılandırılmış ya da yapılandırılmamış olarak sınıflandırılabilir. Yapılandırılmış görüşmeler, daha önceden belirlenmiş standardize soru setinden oluşan mülakatlardır. Yapılandırılmamış görüşmeler, genel bir alanda var olan bilgiyi açığa çıkarmak üzere yapılır ve önceden belirlenmiş bir soru seti yoktur. Yarı yapılandırılmış görüşmeler ise, genel hatlarıyla yol haritasına sahiptir ancak cevaplayıcının ilgi ve bilgisine göre, bu genel çerçeve içerisinde farklı sorular sorarak, konunun değişik boyutlarını ortaya çıkarmaya çalışır (Altunışık vd., 2007; Üzümcü 2015).

En fazla 10 en az 6 üye ile tamamlanabilen odak grup görüşmelerinin genel amacı; farklı gruplara mensup kişiler arasındaki benzerlik veya farklılıkları; bu kişilere ait bireysel veya ortak kültürel özellikleri anlamak bu kişilerin değişik konulardaki görüş, düşünce ve tavırlarına açıklık getirmektir. Kruegere (1994) karışık problemlerle karşılaşılabildiğinden odak grup boyutunun yedi katılımcıdan daha fazla olmaması gerektiğini bahsederken büyük sayıdaki odak grup görüşmelerinin bölünebileceğinden bahsetmektedir (Ersin ve Bayyurt, 2015: 203-204). Turist rehberleri ile 29/11/2017 tarihinde yapılan odak grup çalışmasına toplamda 7 rehber katılmıştır. Odak grup çalışması için seçilen turist rehberlerinin yerliler ile paket turlarda görev almaları gözetilmiştir. Odak grup görüşmesine katılımları rica edilmiş ve alınan olumlu cevaplardan sonra odak grup görüşmesi için tarih belirlenmiş ve turist rehberleri davet edilmiştir. Odak grup görüşmesinin yapılacağı günden bir gün önce turist rehberleri tekrar aranmış ve yedek olarak bekleyen turist rehberi de bu gruba dahil edilmiştir. Ayrıca odak grup çalışmasının yapılacağı salon bir gün önceden ışık, ses ve teknolojik olanaklar açısından kontrol edilmiş ve oturma düzeni herkesin birbirini ve araştırmacıyı göreceği şekilde ayarlanmıştır. Görüşmenin yapılacağı sürenin erken bir saat olması sebebiyle görüşmeye katılacak turist rehberleri için içecek ve atıştırmalık aperatifler hazırlanarak görüşmenin yapılacağı salona düzgün bir şekilde sıralanmıştır. Odak grup görüşme saatinden 25 dakika önce tüm turist rehberleri telefon ile tekrar aranmış ve bir tanesinin gelemeyeceği öğrenilmiştir. Yedek olarak bekleyen turist rehberine telefon ile ulaşılarak görüşmeye davet edilmiştir. Yedek olan turist rehberi ile bir buluşma noktası belirlenmiş, diğer turist rehberleri karşılanmış ve sohbet eşliğinde bir şeyler içmeleri sağlanırken yedek olan turist rehberi buluşma noktasından araç ile alınmış ve görüşmenin yapılacağı yere getirilmiştir.

\subsection{Verilerin Analizi}

İçerik analizleri yapılmadan bir önceki safhada verilerin gruplandırılması yapılırken, öncelikle hazırlanan araştırma sorusundan sonra odak grup çalışması verilerinin kayıtlarının analizi için üç akademisyenin görüşleri alınarak paket turlarda 
yaşanabilecek sorunların nerelerde yaşanabileceği ortaya konulmuştur. Daha sonrasında yani verilerin analizlerinde, önceki bölümlerde belirtilmiş olduğu gibi etik değerlerden iyi-kötü, özgürlük, erdem, adalet, vicdan, görev ve sorumluluk yargılarından faydalanılmış ve yasaları dikkate alarak analizler tamamlanmıştır. Bu bağlamda odak grup görüşmesi sırasında oturuma katılan turist rehberlerine; Yerli turistler paket turlarda etik dışı davranışlarda bulunmakta mıdırlar? sorusu sorulmuş ve kayıt altına alınan veriler içerik analizine tabi tutulmuştur ve 8 tema altında gruplanmıştır. Bu temalar bulgular kısmında açıklanmıştır.

\section{Odak Grup Çalışması Bulguları}

Odak grup çalışmasına katıım sağlayan rehberlere yöneltilen sorular ve bu sorulara verilen cevaplar aşağıdaki gibi sıralanmaktadır. Turist rehberlerinin bahsetmiş oldukları maddelerin etik ilkeler açısından yorumlanması kısmında; sorumluluk, özgürlük ve adalet gibi etik değerlere aykırı davranışlar dikkate alınmıştır.

Turunuz sırasında gittiğiniz müze ve örenyerlerinde karşılaştığınız etik dışı turist davranışları nelerdir?

1. Buraya dağ, taş görmeye mi geldik şeklinde serzenişte bulunulması,

2. Tarihi eserlere zarar verilmesi,

3. Yüksek sesle konuşarak diğer turist veya yerlilerin rahatsız edilmesi,

4. Müze / örenyeri kurallarına uyulmaması,

5. Müze / örenyerinde sigara içilmesi ve yere atılması,

6. Toplanma yerine zamanında gelinmemesi,

7. Diğer grupların müze-örenyeri giriş ve çıkışlarında geçişinin engellenmesi,

8. Örenyeri girişinde sıra beklemek istenmemesi,

9. Grup ile hareket ederken gruptan ayrılmak davranışı sergilenmesi,

10. Tur programının değiştirmek için çabalanması.

Çıktığınız turlarda yemek yediğiniz yerlerde karşılaştığınız etik dışı turist davranışları nelerdir?

1. Yemek için rezerve edilmiş olan masaya oturmak istememesi,

2. Açık büfeden aldıkları yiyecekleri israf etmeye çalışması,

3. Diğer turistlerin rahatsız edilmesi,

4. Yemekten sürekli şikayet edilmesi,

5. Diğer turistlere ayrılan içeceklerin alıp içilmesi,

6. İki kişinin yemek yemesine rağmen ücreti tek kişi yemek yedik diyerek düşük ödemeye çalışması,

7. Yemek zamanlarına itiraz edilmesi,

8. Verilen siparişi diğer yemeği gördükten sonra değiştirmek istemesi,

9. Yemeğe dışarıdan içecek getirilmesi.

\section{Çıktığınız turlarda size karşı yapılan etik dışı turist davranışları nelerdir?}

1. Programı okumadan tura katılma davranışı sergilenmesi,

2. Serbest zaman verilmeden fotoğraf çekip dikkat dağıtılması,

3. Anlatım yaparken yüksek sesle konuşulması, şarkı söylenmesi, biz buraları biliyoruz denmesi veya tekrar anlatım istenmesi,

4. Rehbere argo tavirlarla hitap edilmesi,

5. Kendini tanıtmış olan rehbere "sen kimsin diye sorularak rahatsız edilmesi",

6. Rehberin koltuğunun gasp edilmeye çalışılması, 
7. Rehberden araç içi ikram istenmesi,

8. Rehberin tarzına saygısızca laf edilmesi,

9. Sürekli sigara molası isteyerek tur programının değiştirilmek istenmesi,

10. Tur sırasında verilen rotalara dikkat etmeyip kaybolmak.

\section{Çıktığınız turlarda turistlerin birbirlerine karşı yaptıkları etik dışı davranışlar nelerdir?}

1. Yemek zamanlarında masalara çanta bırakılarak rezervasyon yapılmaya çalışma,

2. Başkasının sırasının alınması,

3. Otobüste diğer turistlerle yer kavgası yapılması,

4. Geç kalan turistlerin diğer turistlerden özür dilemesi yerine laf etmesi. nelerdir?

Çıktığınız turlarda turistlerin otobüste yaptıkları etik dışı davranışlar

1. Otobüs içerisinde sürekli yüksek sesle konuşulması,

2. Otobüs içerisinin kirletilmesi,

3. Emniyet kemeri takmayıp sürekli otobüste dolaşılması,

4. Otobüste şarkı söylenmesi,

5. Otobüse ıslak kıyafetlerle oturulması,

6. Otobüse taşınmaması yasak olan yiyeceklerin getirilmesi,

7. Otobüste dans etme isteği.

Çıktığınız turlarda sabah otelden ayrılırken ve akşam otele vardığınızda karşılaştığınız etik dışı turist davranışları nelerdir?

1. Otelden ayrılırken anahtar teslim edilmemesi,

2. Otel ekstralarının ödenmemesi,

3. Açık büfeden yiyecek alarak otobüste yenmesi,

Çıktığınız turlarda otele vardığınızda karşılaştığınız etik dışı turist davranışları nelerdir?

1. Otel girişlerinde "bize iyi oda ver" diyerek rehberin taciz edilmesi,

2. Otel girişinde anahtar için beklemek istenmemesi.

Çıktığınız turlarda turistlerin otobüs kaptanına yaptıkları etik dışı davranışlar nelerdir?

1. Otobüste sürekli kaptanla konuşarak dikkat dağıtılması,

2. Kaptana yemekte öncelik verilmemesi,

3. Bagajdan sürekli bir şeyler almak istenilmesi,

4. Şarj aletleri için kaptanın sürekli rahatsız edilmesi,

5. Kaptana kötü davranılması,

6. Kaptanın DJ gibi kullanılmaya çalışııması,

7. Kaptanın tur süresini uzatmasının istenmesi,

\section{Sonuç ve Öneriler}

Araştırma kapsamında tamamlanan odak grup çalışmasının sonuçlarına göre dikkat çeken etik dışı turist davranışları, örenyeri /müze kurallarına uymamak, diğer turistleri 
rahatsız etmek (yüksek sesle konuşmak, sıra kavgası yapmak), programı okumadan tura katılım sağlamak şeklinde sıralanmıştır. Bu davranışlarla birlikte tur programına müdahale etmek, serbest zaman verilmeden fotoğraf çekip dikkat dağıtmak, turist rehberi anlatım yaparken yüksek sesle konuşmak, "biz buraları zaten biliyoruz" demek veya tekrar anlatım istemek, rehberin lafını bölmek gibi davranışlar da sıklıkla gerçekleşmektedir. Rehbere argo tavırlarla hitap etmek, otobüsü kirletmek, emniyet kemeri takmadan yolculuk yapmak, otel ekstralarını ödememek, otobüs kaptanına kötü davranmak, otobüs kaptanına sürekli bagaj açtırmaya çalışmak, kaptandan geri dönüşlerde duraklar harici yerlerde indirmesini istemek gibi davranışlar odak grup çalışmasına katılan rehberler tarafından dile getirilmiştir.

Dünya Turizm Örgütü'nün belirlemiş olduğu Küresel Turizm Etik Kodlarında yer alan etik ilkeler içinde yer alan "turizmin toplumlararası karşılıklı anlayışa katkısı içerisinde bulunan turizm faaliyetleri ev sahibi bölge ve ülkenin özellik ve gelenekleriyle uyum içinde, alışkanlık ve yasalarına saygı gösterilerek gerçekleştirilmelidir" ilkesi evrensel değerlerin gerekliliğini vurgulamaktadır. Ayrıca etik değerler kapsamında yer alan görev ve sorumluluklar ve yasalarla alakalı olan maddelere dikkat çekilmektedir. Bununla birlikte örneğin yere çöp atmak yasalara aykırı bir davranıştır ve Kabahatler Kanunu (Mevzuat, 2018) 5326 numaralı kanunun, 39. ve 41. maddelerince yasalara uygun olmayan davranışların karşılığı olarak bu davranışta bulunanlar cezalandırılabilecektir. Dolayısıyla etik dışı davranışlardan bazılarının aynı zamanda yasalara ve küresel etik kodlara da aykırı olduğunun turistlerce bilinmesi önemlidir. Etik dışı davranmanın bir yaptırımının olabileceğinin turistlere iletilmesi bu açıdan gerekli bir önlem olarak görülebilir.

Etik dışı turist davranışlarının saptanması sonucunda etik kodlar (rehberler) oluşturularak turizm işletmelerinin ve çalışanlarının daha bilinçli ve etik açıdan daha donanımlı tüketici ile karşılaşması sağlanacaktır. Bunun sonucunda turistlerin katıldıkları turlardan daha verimli dönmelerine, daha iyi tatil geçirmelerine katkıda bulunulurken aynı zamanda tur çalışanlarının iş motivasyonlarının ve tatminlerinin artarak turun niteliğinin artması sağlanacaktır.

Hazırlanan etik kodların sonrasında turizm işletmelerinde bu etik kodların öğrenilmesi konularında destek eğitimler verilerek oluşturulan kodun daha etkili hale getirilmesi çalışmanın verimliği açısından görülebilir. Bunun yanında etik kodların içerisinde hangi maddelerin yer aldığı ile ilgili el broşürü hazırlanarak turist rehberlerine verilmesi ile birlikte turist rehberlerinin de daha etkili olarak etik maddeler konusunda bilgi sahibi olmaları sağlanabilir.

Ortaya çıkan etik kodlar sonrasında kamu spotlarında yapılacak çalışmalar ile birlikte daha bilinçli bir tüketici kitlesi oluşması sağlanabilecektir. Ayrıca hazırlanacak olan etik dışı davranışların belirtildiği bilgilendirme yazılarının turistlere dağıtılması ile birlikte daha bilinçli bir tüketici kitlesinin ortaya çıkması sağlanabilir.

Zaman ve maddi kısıtlardan ötürü çalışma yerli turistlerin etik dışı davranışlarını konu almaktadır. Gelecekte yabancı turistlerin de etik dışı davranışları ortaya konulabilir ve böylece etik ve kültür ilişkisi de incelenebilir.

\section{Kaynakça}

Alkan, D. P. (2016). Etik Liderlik. İstanbul: Derin Yayınları.

Akarsu, B. (1984). Felsefe Terimler Sözlüğü. Ankara: Savaş Yayınları. 
Akçay, S., Yağcı K., Efendi M. (2018). Paylaşmak mı Paylaşmamak mı? Balıkesir: Turizm Rehberliği Kongresi.

Altunışık R., Coşkun R., Bayraktaroğlu S. ve Yıldııım E. (2007). Sosyal Bilimlerde Araştırma Yöntemleri-SPSS Uygulamalı, Sakarya: Sakarya Yayıncılık.

Arslan, M., Akıncı, S. K., ve Karapınar, P. B. (2007). E-Iş, E-Devlet, Etik. Ankara: Siyasal Kitabevi.

Aslan, A., ve Kozak, M. (2012). Customerdeviance in resorthotels: Thecase of Turkey. Journal of Hospitality Marketing \& Management, 21(6), 679-701

Bauman, Z. (2016). Postmodern Etik (Cilt 3). (A. Türker, Çev.) İstanbul, Cağaloğlu: Ayrıntı.

Cevizci, A. (2008). Etiğe Giriş. İstanbul: Paradigma Yayınları.

Cole, S. (2007). Implementing and evaluating a code of conduct for visitors. Tourism Management, 28 (2). s. 443-451.

Creswell, J. W. (2016). Nitel Çalışma Tasarımı. M. Bütün, ve S. B. Demir içinde, Nitel Araştırma Yöntemleri (A. Budak, ve İ. Budak, Çev., Cilt 3, s. 42-68. Ankara: Siyasal Kitabevi.

Dedeoğlu, G. (2004). Etik Düşünce ve Postmodernizm. Telos Yayınları.

Dedeoğlu, G. (2016). Teknoloji, İletişim, Yeni Medya ve Etik. İstanbul: Sentez Yayıncilık.

Demircan, M. (2007). Vergi Hukuku Açısından Profesyonel Turist Rehberliği. Ankara: Detay Yayıncılık.

Denzin, N. K. ve Lincoln, S. Y. (2008). Strategies of Qualitative Inquiry, Handbook of Qualitative Research, 3rd Edition.

Gök, S. (2012). Çalışma Yaşamında Etik. S. Gök, B. D. Oral, B. Özer, T. Ural, H. B. Buzlu, T. Bıyıklı; içinde, Etik (s. 1-26). İzmir: Zeus Yayınları.

Grimwood, S. B., Yudina, O., Muldoon, M., ve Qiu, J. (2015), Responsibility in tourism: A discursive analysis. Annals of Tourism Research , 50, s. 22-38.

Gülbuğ, E. (2012). Illetişim ve Etik. İstanbul: Hiperlinkı Yayınları.

Güler, O., Dalgıç, A. ve Kadıoğlu, C. T. (2017). Gayri Ahlaki Müşteri Davranışı ve Başa Çıkma Taktikleri: Restoran ve Otel Çalışanları Üzerine Bir Araştırma. Mersin Üniversitesi Sosyal Bilimler Dergisi, 632-645.

Harris, L. C. ve Reynolds, K. L. (2003). The consequences of dys functional customer behavior. Journal of Service Research, 6(2), 144-161.

İslamoğlu, H. (2009). Sosyal Bilimlerde Araştırma Yöntemleri. İzmit. Beta Yayınları.

Keskin, D. A. (2014). Meleki Etik . İstanbul: Beta.

Kolçak, M. (2012). Meslek Etiği. Ankara: Murathan Yayınevi.

Kozak, M. A., ve Nergiz, H. G. (2016). Turizmde Etik. Ankara: Detay Yayıncılık.

Kuçuradi, I. (1986) İnsan Hakları Açısından Dünya Problemleri. Dünya Problemleri Karşısında Felsefe . (T. F. Kurumu, Dü.) Ankara: Meteksan.

Kuçuradi, I. (2014). Uludağ Konuşmaları. Ankara: Türkiye Felsefe Yayınları.

Kuehn, M. (2011). Immanuel Kant. Çev: Bülent O. Doğan, Türkiye İş Bankası Kültür Yayınları, İstanbul.

Lovelock, C. H. ve Wright, L. (1999). Principles of service marketing and management. Prentice Hall

Mısırı, I. (2005). Seyahat Acentacılığı ve Tur Operatörlüğü. Ankara: DetayYayıncılık.

Okay, A. ve Okay, A. (2005). Halkla Ilişkiler Kavram Strateji ve Uygulamaları. İstanbul: Der Yayınları.

Öter, Z. (2007). Turist Rehberliğinde Etik. Ö. Güzel, V. Altıntaş, \& İ. Şahin içinde, Turist Rehberliği Araştırmaları, s. 101-121. Ankara: Detay Yayıncılık.

Pieper, A. (2012). Etiğe Giriş (2. Baskı b.). (V. Atayman ve G. Sezer, Çev.) İstanbul: Ayrıntı Yayınları.

Resmi Gazete. (2018, Ocak 8). Nisan 9, 2018 tarihinde Karayolu Taşıma Yönetmeliği: www.resmigazete.gov.tr adresinden alındı 
Sakarya, Ş., ve Kara, S. (2010). Türkiye'de Muhasebe Mesleği Etiğine Yönelik Düzenlemeler ve Meslek Mensupları Tarafından Algılanması Üzerine Bir Alan Araştırması. KMÜ Sosyal ve Ekonomik Araştırmalar Dergisi , s. 57-72.

Sidani, Y., Zbib, I., Rawwas, M. ve Moussawer, T. (2009). Gender, Age, and Ethical Sensitivity: The Case of Lebanese Workers. Gender in Management: An International Journal .

Sökmen, A., ve Tarakçıoğlu, S. (2013). Mesleki Etik. Ankara: Detay Yayıncılık.

Stroll, A., Long, A., Bourke, V. ve Campbell, R. (2014). Etik Kuramları (3. Baskı b.). (M. Türkeri, Çev.) Antalya: Lotus Yayınları.

Tepe, H. (1998, Ağustos; Eylül; Ekim). Bir Felsefe Dalı Olarak Etik: Etik Kavramı, Taraihçesi ve Günümüzde Etik. Doğu Batı (4), s. 15.

Tokat, B., ve Kara, H. (2003). Trafik Kazalarının Azaltılmasında Yetiştirilmiş İnsan Kaynaklarının Rölü: Dumlupınar Üniversitesi Karayolu Taşımacılığı Hizmetleri Bölümü Örneği. Dumlupınar Üniversitesi Sosyal Bilimler Dergisi (8), 1-13.

Türkiye Rehberler Odası(2018). Etik Kurallar ve Meslek Standartları. Haziran 5, 2018 tarihinde http://iro.org.tr/tr/49-page-etik-kurallar-ve-meslek-standartlari.aspx adresinden alındı.

Üzümcü P. T. (2015). Otel Yöneticilerinin Turizm Eğitimine Yönelik Algıları: Kocaeli İli Otel Yöneticileri Üzerinde Bir Araştırma. Kocaeli Üniversitesi Sosyal Bilimler Dergisi, (30), 123-150.

Yıldırım A., ve Şimşek H. (2006). Sosyal Bilimlerde Nitel Araştırma Yöntemleri. 5.Baskı, Ankara: Seçkin Yayınevi 